\section{Anticipated Negative Responses by Students to Possible Ebola Virus Outbreak, Guangzhou, China}

\author{
Joseph T.F. Lau, Zixin Wang, Yoona Kim, Jing Gu, \\ Anise M.S. Wu, Qianling Zhou, Chun Hao, \\ Perry Cheng, Yuantao Hao
}

\begin{abstract}
Author affiliations: Centre for Medical Anthropology and Behavioral Health, Sun Yat-sen University, Guangzhou, China (J.T.F. Lau); Shenzhen Research Institute, The Chinese University of Hong Kong, Shenzhen, China (J.T.F. Lau); Jockey Club School of Public Health and Primary Care, The Chinese University of Hong Kong, Hong Kong, China (J.T.F. Lau, Z. Wang, Y. Kim, Q. Zhou, P. Cheng); Sun Yat-sen University School of Public Health, Guangzhou, China (J.
\end{abstract} Gu, C. Hao, Y. Hao); University of Macau, Macau, China (A.M.S. Wu)

\section{DOI: http://dx.doi.org/10.3201/eid2201.150898}

To the Editor: In 2014, a serious Ebola virus disease (EVD) outbreak occurred in West Africa (1). In a study on EVD-related perceptions, $85 \%$ of US respondents mistakenly believed that EVD could be transmitted through airborne droplets from patients' sneezes or coughs (2). EVDrelated panic was reported in the United States (3) and the United Kingdom (4).

During November 15-December 20, 2014, we conducted a cross-sectional survey of 1,295 undergraduate students in Guangzhou, China, where the population of immigrants from Africa is high (online Technical Appendix, http://wwwnc.cdc.gov/EID/article/22/1/15-0898Techapp1.pdf). Our aim was to measure students' anticipated negative emotional responses and avoidance activities (dependent variables) to a possible outbreak of EVD (5). We constructed scales for the dependent and independent variables to assess EVD-related perceptions: 1) misconceptions/knowledge about transmission modes, 2) scenarios of an EVD outbreak in Guangzhou (chances, severity, control), 3) efficacy of preventive measures and self-protection, and 4) public stigma toward EVD survivors. MLwiN 2.30 (Centre for Multilevel Modeling, University of Bristol, Bristol, UK) was used for multilevel regression analyses (online Technical Appendix).

We analyzed data from $1,155(89.2 \%)$ students who had heard of EVD. To the example of 2-3 EVD cases detected in Guangzhou, $31.0 \%$ showed $\geq 4$ types of anticipated negative emotions (e.g., fear, panic, worry); 59.5\% showed $\geq 3$ types of anticipated unnecessary avoidance. Most $(80.0 \%)$ indicated $\geq 1$ misconception regarding transmission mode (e.g., believed it was droplet or waterborne) but knew that direct contact with the corpse of an infected person $(69.0 \%)$ and body fluids $(81.4 \%)$ could lead to infection and perceived EVD as fatal $(85.6 \%$,) and highly infectious $(81.6 \%)$. About half of respondents believed that effective treatment and a vaccine were unavailable (51.9\% and 59.1\%, respectively); $22.2 \%$ anticipated EVD outbreaks among Africans in Guangzhou (during the next 12 months). Many students perceived severe consequences if a small EVD outbreak occurred in Guangzhou and believed an outbreak would have a high fatality rate $(70.5 \%)$, EVD is highly infectious (65.4\%), an outbreak would be of long duration $(47.5 \%)$, and the number of infected persons would be high $(39.9 \%) ; 52.5 \%-79.2 \%$ of respondents lacked confidence in the government's ability to control an outbreak (e.g., ability to provide adequate vaccines, medication, protective gear). Half or more of respondents believed that restricting travel by Africans to and from Africa and avoiding visiting African-inhabited areas were effective means of prevention. About $40 \%$ were confident that they could protect themselves or family members from EVD (online Technical Appendix Tables 1,2).

Older age, female sex, longer school years, and rural origin were associated with negative emotional responses, avoidance, or both (online Technical Appendix Table 3). In multivariate analyses that adjusted for significant background variables, we found positive associations between both dependent variables and the following independent variables: perceived fatality of EVD, perceived nonavailability of treatment, misconceptions regarding modes of transmission, perceived severity of a Guangzhou outbreak, perceived efficacy of restricting Africans' travel, perceived efficacy of avoiding African-inhabited areas, and public stigma toward EVD survivors. Confidence in governmental control was negatively associated with both dependent variables. Some variables were positively associated with emotional response but not avoidance (perceived irreversible harm, perceived chance of outbreak in Guangzhou and in other parts in China, perceived self-efficacy for protection); 2 variables (perceived nonavailability of vaccine and knowledge of transmission mode) were positively associated with avoidance measures but not with emotional responses (Table).

Because EVD causes serious physical harm, negative emotional responses and unnecessary avoidance practices were anticipated. Such negative community responses might cause individual and societal harm, as witnessed during the epidemic of severe acute respiratory syndrome (6). Misconceptions concerning transmission modes were prevalent and significantly correlated with both dependent variables. More than $80 \%$ of respondents perceived that the virus was highly infectious, another significant factor.

About $20 \%$ of participants believed that an EVD outbreak would occur in Guangzhou in the next year. Among all participants, many anticipated severe outcomes but 
Table. Factors associated with anticipated responses to EVD, adjusted for sociodemographic variables, Guangzhou, China, 2014*

\begin{tabular}{|c|c|c|c|c|}
\hline \multirow[b]{2}{*}{ Factor } & \multicolumn{2}{|c|}{$\begin{array}{c}\text { Emotional Response to } \\
\text { Ebola Scale } †\end{array}$} & \multicolumn{2}{|c|}{$\begin{array}{l}\text { Unnecessary Avoidance } \\
\text { Scale } \ddagger\end{array}$} \\
\hline & $\beta(\mathrm{SE})$ & $\mathrm{p}$ value & $\beta(\mathrm{SE})$ & $\mathrm{p}$ value \\
\hline \multicolumn{5}{|l|}{ Perceived severity of EVD } \\
\hline EVD is fatal & $1.270(0.928)$ & 0.171 & $0.855(0.388)$ & 0.027 \\
\hline EVD causes irreversible harm to physical health & $2.647(0.637)$ & $<0.001$ & $0.504(0.064)$ & 0.064 \\
\hline Perceived fatality of EVD & $2.545(0.635)$ & $<0.001$ & $1.177(0.269)$ & $<0.001$ \\
\hline Perceived high infectivity of EVD & $1.568(0.842)$ & 0.063 & $1.273(0.350)$ & $<0.001$ \\
\hline \multicolumn{5}{|l|}{ Treatment and vaccine availability } \\
\hline Treatment not available & $2.143(0.639)$ & $<0.001$ & $1.108(0.271)$ & $<0.001$ \\
\hline Vaccine not available & $1.236(0.654)$ & 0.059 & $0.786(0.276)$ & 0.005 \\
\hline \multicolumn{5}{|l|}{ Misconceptions and knowledge about modes of transmission of EVD } \\
\hline Misconceptions about Mode of Transmission Scale & $0.406(0.113)$ & $<0.001$ & $0.214(0.048)$ & $<0.001$ \\
\hline Knowledge about Mode of Transmission Scale & $0.285(0.171)$ & 0.095 & $0.369(0.071)$ & $<0.001$ \\
\hline \multicolumn{5}{|l|}{ Perceptions related to EVD outbreak } \\
\hline Chances of Outbreak Scale-Guangzhou & $0.688(0.091)$ & $<0.001$ & $0.064(0.039)$ & 0.100 \\
\hline Perceived Chances of Outbreak Scale-Other Parts of China & $0.986(0.189)$ & $<0.001$ & $0.151(0.081)$ & 0.062 \\
\hline Perceived Severity of Outbreak in Guangzhou Scale & $0.825(0.072)$ & $<0.001$ & $0.222(0.031)$ & $<0.001$ \\
\hline Confidence in Governmental Control Scale & $-1.024(0.086)$ & $<0.001$ & $-0.192(0.038)$ & $<0.001$ \\
\hline \multicolumn{5}{|l|}{ Perceived efficacy and self-efficacy } \\
\hline Perceived Efficacy of Restricting Africans Travel Scale & $1.003(0.176)$ & $<0.001$ & $0.543(0.073)$ & $<0.001$ \\
\hline Perceived Efficacy of Avoidance Scale & $0.544(0.138)$ & $<0.001$ & $0.595(0.056)$ & $<0.001$ \\
\hline Perceived Self-Efficacy for Protection against EVD Scale & $-0.571(0.145)$ & $<0.001$ & $-0.112(0.062)$ & 0.070 \\
\hline \multicolumn{5}{|l|}{ Public stigma toward EVD survivors } \\
\hline Public Stigma Scale & $0.231(0.032)$ & $<0.001$ & $0.125(0.013)$ & $<0.001$ \\
\hline \multicolumn{5}{|c|}{ 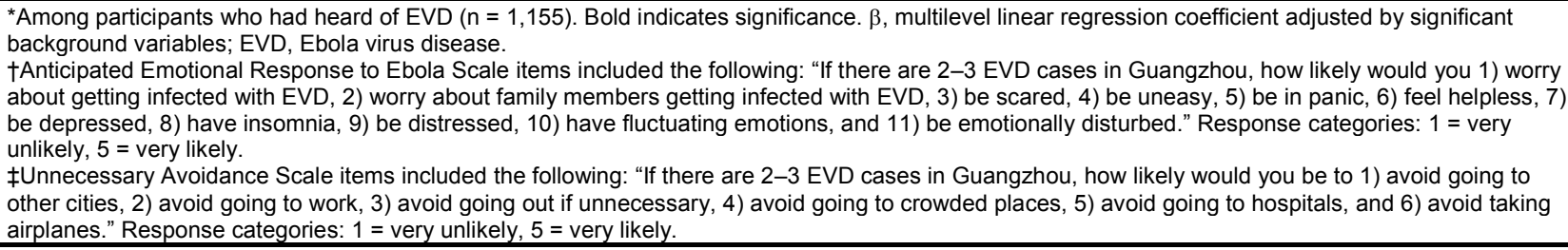 } \\
\hline
\end{tabular}

were not confident that the government was prepared for and could control such an outbreak.

The concentration of immigrants from Africa in this region might have increased perceived chances of an EVD outbreak and thus lead to avoidance of this population. The high percentages of those who believed that restricting Africans' travel was effective also might result in discrimination.

Public stigmatization toward EVD survivors, another significant factor, was a prominent attitude $(7,8)$. Fear, misconceptions, and perceived likelihood of EVD to cause death may lead to patient stigmatizing, which could hinder case detection and patients' service seeking. The relationship between stigmatization and EVD-related perceptions should be investigated.

The study's limitations included the inability to assess real responses, inability to generalize findings to all university students and the general public, and the use of scales that had not been validated. Also, some students might have given exaggerated responses.

In summary, misconceptions and perceptions regarding EVD may result in negative community responses in Guangzhou. Health education is needed to clarify that EVD is not airborne or waterborne or highly infectious and that avoidance is not an effective preventive measure. In addition, the government should start developing and publicizing its preparedness plans.

\section{Acknowledgments}

We thank all research assistants and those who participated in the study.

\section{References}

1. World Health Organization. Ebola situation report, November 26, 2014 [cited 2014 Dec 29]. http://apps.who.int/ebola/ en/ebola-situation-report/situation-reports/ebola-situation-report26-november-2014

2. Harvard T.H. Chan School of Public Health News. Poll: most believe Ebola spread by multiple routes [cited 2014 Dec 18]. http://www.hsph.harvard.edu/news/press-releases/poll-finds-mostbelieve-ebola-spread-by-multiple-routes/

3. Merino JG. Response to Ebola in the US: misinformation, fear, and new opportunities. BMJ. 2014;349:g6712. http://dx.doi.org/ 10.1136/bmj.g6712

4. Joffe H, Haarhoff G. Representations of far-flung illnesses: the case of Ebola in Britain. Soc Sci Med. 2002;54:955-69. http://dx.doi.org/10.1016/S0277-9536(01)00068-5

5. Castillo R. Feeling at home in the "Chocolate City": an exploration of place-making practices and structures of belonging amongst Africans in Guangzhou. Inter-Asia Cult Stud. 2014;15:235-57. http://dx.doi.org/10.1080/14649373.2014.911513

6. Ko CH, Yen C, Yen J, Yang M. Psychosocial impact among the public of the severe acute respiratory syndrome epidemic in Taiwan. Psychiatry Clin Neurosci. 2006;60:397-403. http://dx.doi.org/10.1111/j.1440-1819.2006.01522.x 
7. Davtyan M, Brown B, Folayan M. Addressing Ebola-related stigma: lessons learned from HIV/AIDS. Glob Health Action. 2014;7. http://dx.doi.org/10.3402/gha.v7.26058

8. Kinsman J. "A time of fear": local, national, and international responses to a large Ebola outbreak in Uganda. Global Health. 2012;8:15. http://dx.doi.org/10.1186/1744-8603-8-15

Address for correspondence: Joseph T.F. Lau, 5F, School of Public Health, Prince of Wales Hospital, Shatin, NT, Hong Kong, China; email: jlau@cuhk.edu.hk

\section{Multiple Fungicide-Driven Alterations in Azole-Resistant Aspergillus fumigatus, Colombia, 2015}

\section{Patrice Le Pape, Rose-Anne Lavergne, Florent Morio, Carlos Alvarez-Moreno}

Author affiliations: Université de Nantes, Nantes, France (P. Le Pape, R.-A. Lavergne, F. Morio); Universidad Nacional de Colombia and Clinica Universitaria Columbia, Bogota, Colombia (C. Alvarez-Moreno)

\section{DOI: http://dx.doi.org/10.3201/eid2201.150978}

To the Editor: We read with interest the report by van der Linden et al. about the prevalence of azole-resistant Aspergillus fumigatus isolates from 19 countries, including 2 from the Americas (Brazil and the United States) (1). Recent reports have suggested a link between use of fungicides in agricultural practices and the presence of triazole-resistant $A$. fumigatus among azole-naive persons (2). These resistant strains harbored the TR34/L98H and TR46/Y121F/T289A mutations in the CYP51A gene and its promoter region. These novel mechanisms of resistance have been reported both in environmental and clinical samples in Europe, Asia, and Africa, suggesting a broad geographic spread. However, clinical isolates from 22 states in the United States (3) and a few isolates from Latin America $(1,4)$ failed to show any fungicide-driven resistance in $A$. fumigatus in these continents, even though use of pesticides is a widespread practice in the Americas. Colombia was ranked fourth in the world in 2010 for the use of pesticides, reportedly using 14.5 tons $/ 1,000$ ha, $30 \%$ of which were fungicides (5). Among the fungicides approved by Colombia's regulatory agency, the Colombian Agricultural Institute (6), tebuconazole and difenoconazole are largely used in the flower industry, more specifically in Cundinamarca, where $60 \%$ of Colombia's flowers are produced.

In 2015, we conducted a study for which 60 soil samples from flower fields and greenhouses were collected in the outskirts of Bogota, Cundinamarca. Samples were inoculated on Sabouraud agar at $43^{\circ} \mathrm{C}$, and positive samples were screened for azole-resistance on agar supplemented with either itraconazole $(4 \mathrm{mg} / \mathrm{L})$ or voriconazole $(4 \mathrm{mg} / \mathrm{L})$. Of the 38 resistant Aspergillus strains, 20 were selected (up to 5 colonies for each positive culture), identified as $A$. fumigatus by $\beta$-tubulin gene sequencing, and analyzed for CYP51A gene alterations (7). Results showed great diversity in molecular resistance with the presence of TR46/ Y121F/T289A ( $\mathrm{n}=17)$, TR34/L98H $(\mathrm{n}=1)$, and TR53 ( $\mathrm{n}=$ 1) mutations; 1 isolate had a wild-type CYP51 sequence ( 8 ).

Our study highlights the presence of $A$. fumigatus harboring fungicide-driven alterations in Colombia, South America. The results indicate the importance of initiating active agricultural surveillance along with close monitoring of drug resistance in clinical isolates from naive and azole-exposed patients in these countries. Clinical management of Aspergillus disease can be challenging because of unfavorable clinical outcomes after patients have acquired multi-azole-resistant strains from the environment (9). Additional studies are needed to evaluate the extent to which pesticide use in floriculture and agriculture (e.g., coffee and banana) contributes to azole resistance in Colombia.

\section{References}

1. van der Linden JWM, Arendrup MC, Warris A, Lagrou K, Pelloux $\mathrm{H}$, Hauser PM, et al. Prospective multicenter international surveillance of azole resistance in Aspergillus fumigatus. Emerg Infect Dis. 2015;21:1041-4. http://dx.doi.org/10.3201/eid2106.140717

2. Snelders E, van der Lee HAL, Kuijpers J, Rijs AJMM, Varga J, Samson RA. Emergence of azole resistance in Aspergillus fumigatus and spread of a single resistance mechanism. PLoS Med. 2008;5:e219. http://dx.doi.org/10.1371/journal.pmed.0050219

3. Pham CD, Reiss E, Hagen F, Meis JF, Lockhart SR. Passive surveillance for azole-resistant Aspergillus fumigatus, United States, 2011-2013. Emerg Infect Dis. 2014;20:1498-503. http://dx.doi.org/10.3201/eid2009.140142

4. Lockhart SR, Frade JP, Etienne KA, Pfaller MA, Diekema DJ, Balajee SA. Azole resistance in Aspergillus fumigatus isolates from the ARTEMIS global surveillance study is primarily due to the TR/L98H mutation in the cyp51A gene. Antimicrob Agents Chemother. 2011;55:4465-8. http://dx.doi.org/10.1128/AAC.00185-11

5. Food and Agriculture Organization of the United Nations Statistics Division. FAOSTAT/agri-environmental indicators/ pesticides. Rome: The Organization; 2015 [cited 2015 May 25]. http://faostat3.fao.org/download/E/EP/E

6. Instituto Colombiano Agropecuario. Registros de venta de plaguicidas químicos de uso agricola—Septiembre 30 De 2015. Bogata (Colombia): The Institute; 2015 [cited 2015 Feb 12]. http://www.ica.gov.co/getdoc/2dae6093-c021-49d1-8b29-c9dfebce2757/REGISTROS-DE-VENTA-PQA-24-01-09.aspx

7. Lavergne RA, Morio F, Favennec L, Dominique S, Meis JF, Gargala G, et al. First description of azole-resistant Aspergillus fumigatus due to TR46/Y121F/T289A mutation in France. Antimicrob Agents Chemother. 2015;59:4331-5. http://dx.doi.org/10.1128/AAC.00127-15

8. Hodiamont CJ, Dolman KM, Ten Berge IJ, Melchers WJ, Verweij PE, Pajkrt D. Multiple-azole-resistant Aspergillus fumigatus osteomyelitis in a patient with chronic granulomatous disease successfully treated with long-term oral posaconazole and surgery. Med Mycol. 2009;47:217-20. http://dx.doi.org/10.1080/13693780802545600 